\title{
Online Student Admission Application at SMK Al-Basyariah Bojong Gede
}

\author{
Dinda Ayu Muthia \\ Sistem Informasi \\ Universitas Bina Sarana Informatika \\ Jakarta, Indonesia \\ dinda.dam@bsi.ac.id
}

\author{
Adi Kurniawan \\ Sistem Informasi \\ Universitas Bina Sarana Informatika \\ Jakarta, Indonesia \\ adie.abay@yahoo.co.id
}

\author{
Andini Ramadhani \\ Sistem Informasi \\ Universitas Bina Sarana Informatika \\ Jakarta, Indonesia \\ ramadhaniandini10@gmail.com \\ Raka Irfansyah \\ Sistem Informasi \\ Universitas Bina Sarana Informatika \\ Jakarta, Indonesia \\ kazekami41@yahoo.com
}

\begin{abstract}
Admission of new students is one of the processes that exist in educational institutions every year, the number of prospective students who register causes the new student admission committee cannot manage everything properly so that it is less effective in handling it. In this study, the new student admission system used by Al-Basyariah Vocational School Bojong Gede still uses manual system, which still uses paper records, so that minimal damage and even data loss occurs. The purpose of this study is to create an online application to help the admission process of new students using the waterfall method. The waterfall method had been used in many research, especially in developing of information system. This online student admission application can save the time needed to register new students to be more efficient because it has been supported by an integrated system and improve the quality and efficiency of the implementation of new student admission registration.
\end{abstract}

Keywords — student; admission; application; online;

\section{INTRODUCTION}

In general, parents have considered and prepared various things before entering their children into a school, including the maturity of their children, which schools are suitable for their children, including how, the teacher, the atmosphere of the school, and the funding. There are many other things that are considered and prepared by parents for their children before determining which school will be assigned the task and the responsibility of educating their children [1].

Admission of new students is a routine activity carried out by educational institutions in each year. In fact, some educational institutions are less prepared in implementing new student admissions. The complexity of administrative problems leads to a lack of efficiency in new student admission activities [2].

This research took place in Al-Basyariah Vocational High School, Bojong Gede. In this school, the new student admission activities has been done manually. There are many problems in the new student admission process, such as, too many forms and documents to be filled and submitted by the prospective students. The process took more time when the parents wanted to know about school information. This school receives many new students each year. That means the queue of registrants could take time in the process of new students admission.

The method that is used in this research is Waterfall method. The waterfall method had been used in many research, such as web based application for new student registration in SMA Negeri 14 Garut [1], online application for student registration in SMK Negeri 3 Yogyakarta [2], and e-enrollment using Customer Relationship Management in Integrated Islamic Elementary School [3].

This research has a purpose to create an online application to help the process of accepting new students using the waterfall method. Making it easier 
for prospective students who want to register to get information, fill out forms, submit documents, and shorten the registration time.

\section{THEORY}

\section{A. Waterfall Model}

In principle, the waterfall model is an example of a plan-driven process. All of the process activities must be planned and scheduled before starting work on them [4]. This model has been illustrated in Fig 1.

Based on Ian Sommerville [4], there are five principal stages of the waterfall model, i.e.:

1. Requirements definition

The system's services, constraints, and objectives are built by consultation with system users. They are serve as a system specification.

2. System and software design

The process of systems design allocates the requirements to either hardware or software systems by building a system architecture.

3. Implementation and unit testing

During this part, the software design is realized as a set of programs or program units. Unit testing purpose is to verify that every unit meets the specification.

4. Integration and system testing

The program units are integrated and tested as an accomplished system to assure that it is fit with the software requirements. After system testing has been done, the software system is delivered to the client.

5. Operation and maintenance

The system is installed and used by the client. Maintenance includes correcting errors which were found after using the system, improving the system with the new requirements.

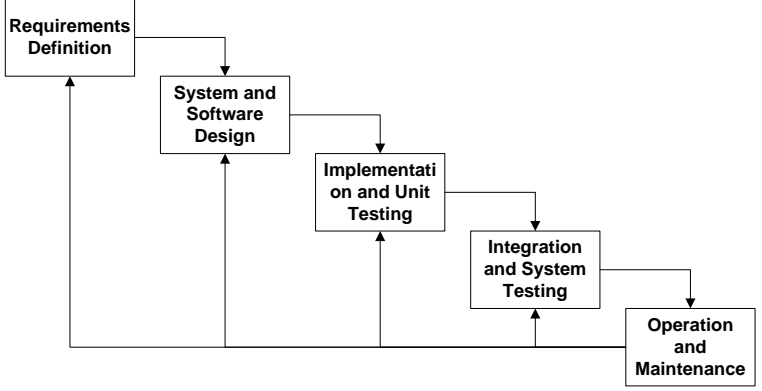

Fig. 1. The Waterfall Model

\section{B. Database}

The Database can be $\mathrm{s}$ as a kind of electronic filing cabinet. The Database is a set of persistent data that is used by the application systems [5].

Based on Christopher J. Date [5], here are some advantages of the database approach:

1) The data can be shared.

2) Redundancy can be reduced.

3) Inconsistency can be avoided (to some extent).

4) It can provide transaction support

5) Integrity can be maintained.

6) Security can be enforced.

7) Balancing conflicting requirements.

8) Standards can be enforced.

\section{Entity Relationship Diagram}

Entity is defined as a thing that can be distinctly identified. Relationship is defined as an association among entities. Entity relationship can be one-to-one, one-to-many, and many-to-many. Entity relationship diagrams is a technique for the logical structure of a database can be represented in a pictorial manner [5].

\section{Unified Modelling Language (UML)}

The Unified Modeling Language (UML) is a modeling language that is used to understand, design, browse, configure, maintain, and control information about such systems [6].

Version 2.4 of the UML consists of fourteen diagramming techniques used to model a system. The diagrams are broken into two major groupings: one for modeling the structure of a system and one for modeling behavior. Structure diagrams provide a way to represent the data and static relationships in an information system. The structure diagrams consist of object, component, deployment, class, composite structure and package diagrams. Behavior diagrams depict the relationships among the instances or objects that represent the business information system. The behaviour modeling diagrams consist of sequence, timing, protocol state machine, communication, activity, interaction overview, use case and behaviour state machine diagrams [7].

In this research, we only use 2 diagrams, such as use case, activity, class, and sequence diagrams. These are the explanation of each diagram based on Alan Dennis [7]:

1) Use case diagram: A use-case diagram illustrates in a very simple way the main functions of the system and the different kinds of users that will interact with it. Use case diagram is drawn when 
gathering and defining requirements for the system.

2) Activity diagram: Activity diagrams are used to model the behavior in a business process independent of objects.

\section{E. Unit Testing}

There are two approaches to unit testing: blackbox testing and white-box testing. Black-box testing is the most commonly used because each class represents an encapsulated object. White-box testing is based on the specifications of the method associated with every class. However, white-box testing has had limited impact in object-oriented development. This is due to the rather small size of the individual methods in a class. Most approaches to testing classes use black-box testing to ensure their correctness [7].

\section{RESULT}

\section{A. Functional Requirements}

In order to find a solution to some problems that is faced by Al-Basyariah Vocational High School, we create a web application so that students admission can be processed online. We design only two users that can access to the web, they are administrator (admin) and new prospective students. Both of these users have different information needs, such as the following:

1) Prospective student's needs:

a) Filling registration form.

b) Filling personal data.

c) Filling parent's data.

d) Filling interview form.

2) Administrator's needs:

a) Administrator can see the number of students who register.

b) Administrator can edit some data if there is error while the prospective student registering online.

c) Administrator can see all complete data about students and parents

\section{B. Database Design}

1) Entity Relationship Diagram

Relationship between entity can be described in Entity Relationship Diagram. Figure 2 illustrated the diagram.

2) Logical Record Structure
Figure 3 illustrates logical record structure of the database design.

\begin{tabular}{|l|}
\multicolumn{1}{|c|}{ Admin } \\
\hline Id \\
AdminName \\
Username \\
Password \\
\multicolumn{1}{|c|}{ M } \\
\hline \multicolumn{1}{|c|}{ Registration } \\
\hline RegistrationNumber \\
Email \\
Department \\
FullName \\
NickName \\
StudentID \\
Gender \\
DOB \\
ChildReligion \\
Citizenship \\
ChildStatus \\
Colloquial \\
Address \\
PhoneNumber \\
Distance \\
JuniorHighSchool \\
DiplomaNumber \\
DurationOfStudy \\
Accepted \\
FatherName \\
MotherName \\
ParentsDOB \\
ParetnsReligion \\
ParetnsCitizenship \\
ParetnsOccupation \\
ParentsIncome \\
ParentsAddress \\
Hobby \\
\hline
\end{tabular}

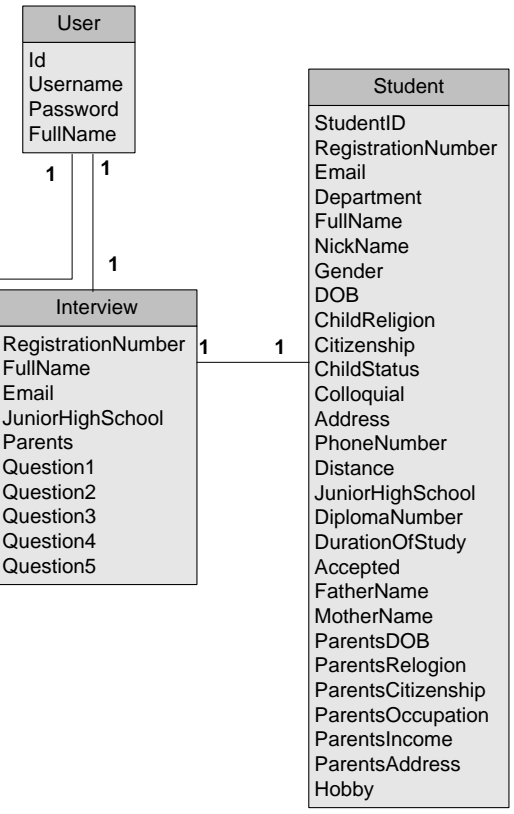

Fig. 3. Logical Record Structure

\section{Use Case Diagram}

The design of use case diagram of the proposed system has been illustrated in Fig. 4.

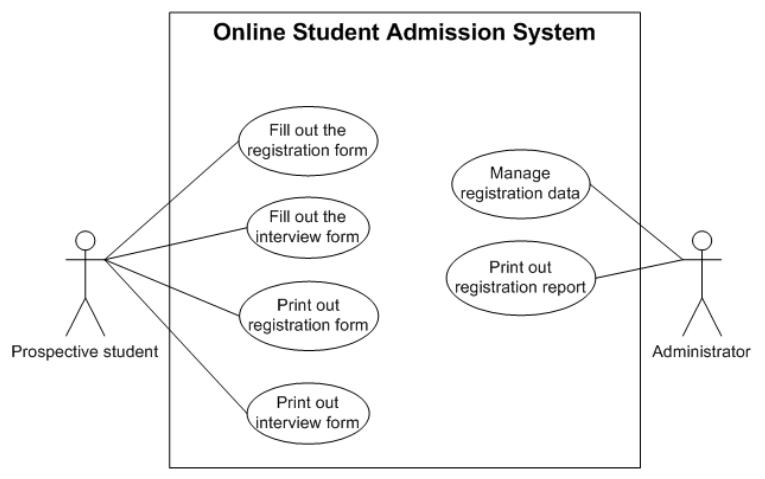

Fig. 4. Use Case Diagram

\section{Activity Diagram}

Activity diagram are made based on each use case. Based on "Fill out the registration form" use case, we can see activity diagram in Fig. 5. 


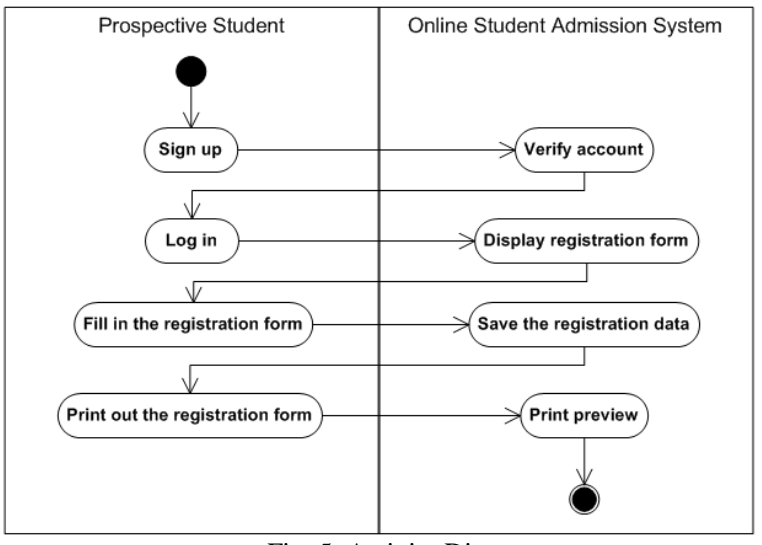

Fig. 5. Activity Diagram

\section{E. Implementaion}

The implementation of proposed system can be seen in Fig. 6. This is a user interface for the prospective student to do online student admission.

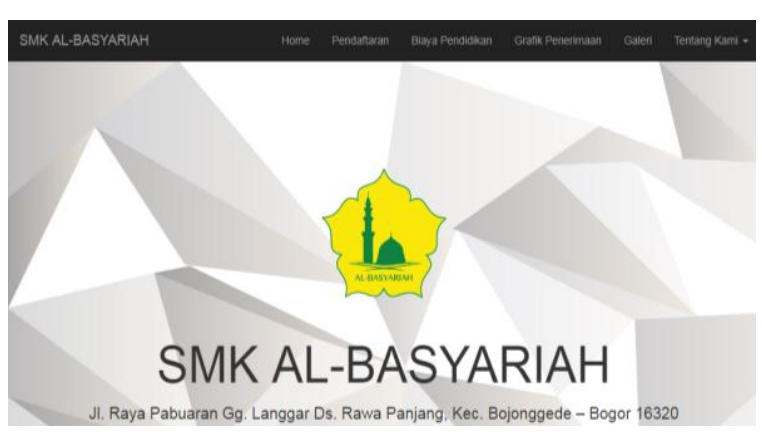

Fig. 6. Home Page

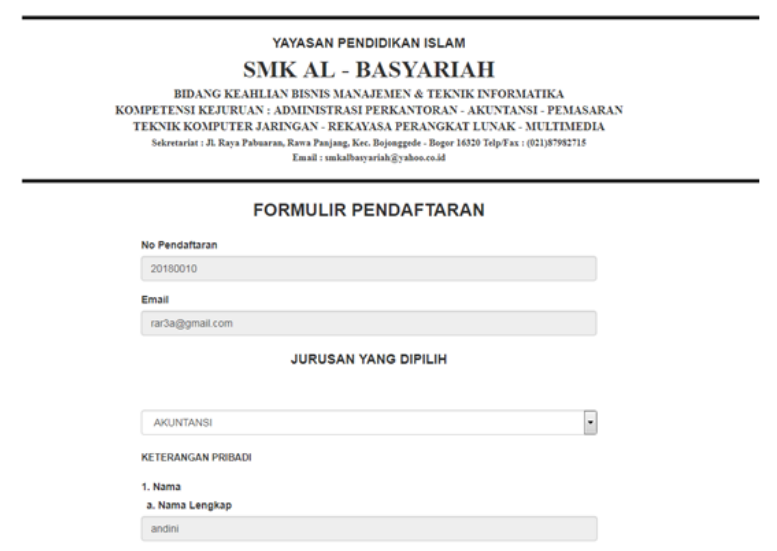

Fig. 7. Registration Form

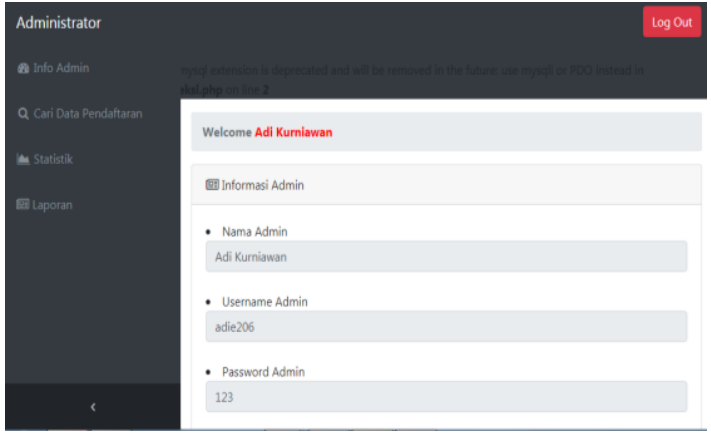

Fig. 8. Administration's Page

\section{F. Black box Testing}

Table 1 described the process of black box testing on administrator's log in page.

TABLE I. BLACK BOX TESTING ON ADMINISTRATOR's LOG IN PAGE

\begin{tabular}{|c|c|c|c|c|c|}
\hline No & $\begin{array}{c}\text { Testing } \\
\text { scenario }\end{array}$ & Test case & $\begin{array}{l}\text { Expected } \\
\text { results }\end{array}$ & Result & $\begin{array}{l}\text { Concl } \\
\text { usion }\end{array}$ \\
\hline 1. & $\begin{array}{l}\text { The Email } \\
\text { and the } \\
\text { phone } \\
\text { number are } \\
\text { not filled } \\
\text { then click } \\
\text { the login } \\
\text { button }\end{array}$ & $\begin{array}{c}\text { Email } \\
\text { (empty) } \\
\text { Phone } \\
\text { Number } \\
\text { (empty) }\end{array}$ & $\begin{array}{l}\text { The system } \\
\text { will deny } \\
\text { user access } \\
\text { and display } \\
\text { "Login } \\
\text { Failed" }\end{array}$ & $\begin{array}{l}\text { Compati } \\
\text { ble to } \\
\text { expectat } \\
\text { ions }\end{array}$ & Valid \\
\hline 2. & $\begin{array}{l}\text { The email is } \\
\text { filled in and } \\
\text { the phone } \\
\text { number is } \\
\text { not filled in } \\
\text { or blank } \\
\text { then click } \\
\text { the login } \\
\text { button }\end{array}$ & $\begin{array}{c}\text { Email } \\
\text { (ara@gm } \\
\text { ail.com) } \\
\text { Phone } \\
\text { Number } \\
\text { (empty) }\end{array}$ & $\begin{array}{l}\text { The system } \\
\text { will deny } \\
\text { user access } \\
\text { and display } \\
\text { "Login } \\
\text { Failed" }\end{array}$ & $\begin{array}{l}\text { Compati } \\
\text { ble to } \\
\text { expectat } \\
\text { ions }\end{array}$ & Valid \\
\hline 3. & $\begin{array}{l}\text { The email is } \\
\text { not filled in } \\
\text { (blank) and } \\
\text { the phone } \\
\text { number is } \\
\text { filled in, } \\
\text { then click } \\
\text { the login } \\
\text { button }\end{array}$ & $\begin{array}{c}\text { Email } \\
\text { (kosong) } \\
\text { Phone } \\
\text { Number } \\
(0897983 \\
43424)\end{array}$ & $\begin{array}{l}\text { The system } \\
\text { will deny } \\
\text { user access } \\
\text { and display } \\
\text { "Login } \\
\text { Failed" }\end{array}$ & $\begin{array}{l}\text { Compati } \\
\text { ble to } \\
\text { expectat } \\
\text { ions }\end{array}$ & Valid \\
\hline 4. & $\begin{array}{l}\text { Fill in one } \\
\text { of the } \\
\text { wrong } \\
\text { conditions } \\
\text { in the email } \\
\text { or phone } \\
\text { number } \\
\text { then click } \\
\text { the login } \\
\text { button }\end{array}$ & $\begin{array}{c}\text { Email } \\
\text { (ara@gm } \\
\text { ail.com) } \\
\text { Phone } \\
\text { Number } \\
(0897983 \\
43421)\end{array}$ & $\begin{array}{l}\text { The system } \\
\text { will deny } \\
\text { user access } \\
\text { and display } \\
\text { "Login } \\
\text { Failed" }\end{array}$ & $\begin{array}{l}\text { Compati } \\
\text { ble to } \\
\text { expectat } \\
\text { ions }\end{array}$ & Valid \\
\hline 5. & $\begin{array}{l}\text { Fill in the } \\
\text { email and } \\
\text { phone } \\
\text { number } \\
\text { with the } \\
\text { correct data } \\
\text { then click }\end{array}$ & $\begin{array}{c}\text { Email } \\
\text { (ara@gm } \\
\text { ail.com) } \\
\text { Phone } \\
\text { Number } \\
(0897834 \\
3424)\end{array}$ & $\begin{array}{l}\text { The system } \\
\text { accepts login } \\
\text { access and } \\
\text { displays } \\
\text { "successful } \\
\text { login" then } \\
\text { immediately }\end{array}$ & $\begin{array}{l}\text { Compati } \\
\text { ble to } \\
\text { expectat } \\
\text { ions }\end{array}$ & Valid \\
\hline
\end{tabular}

64 


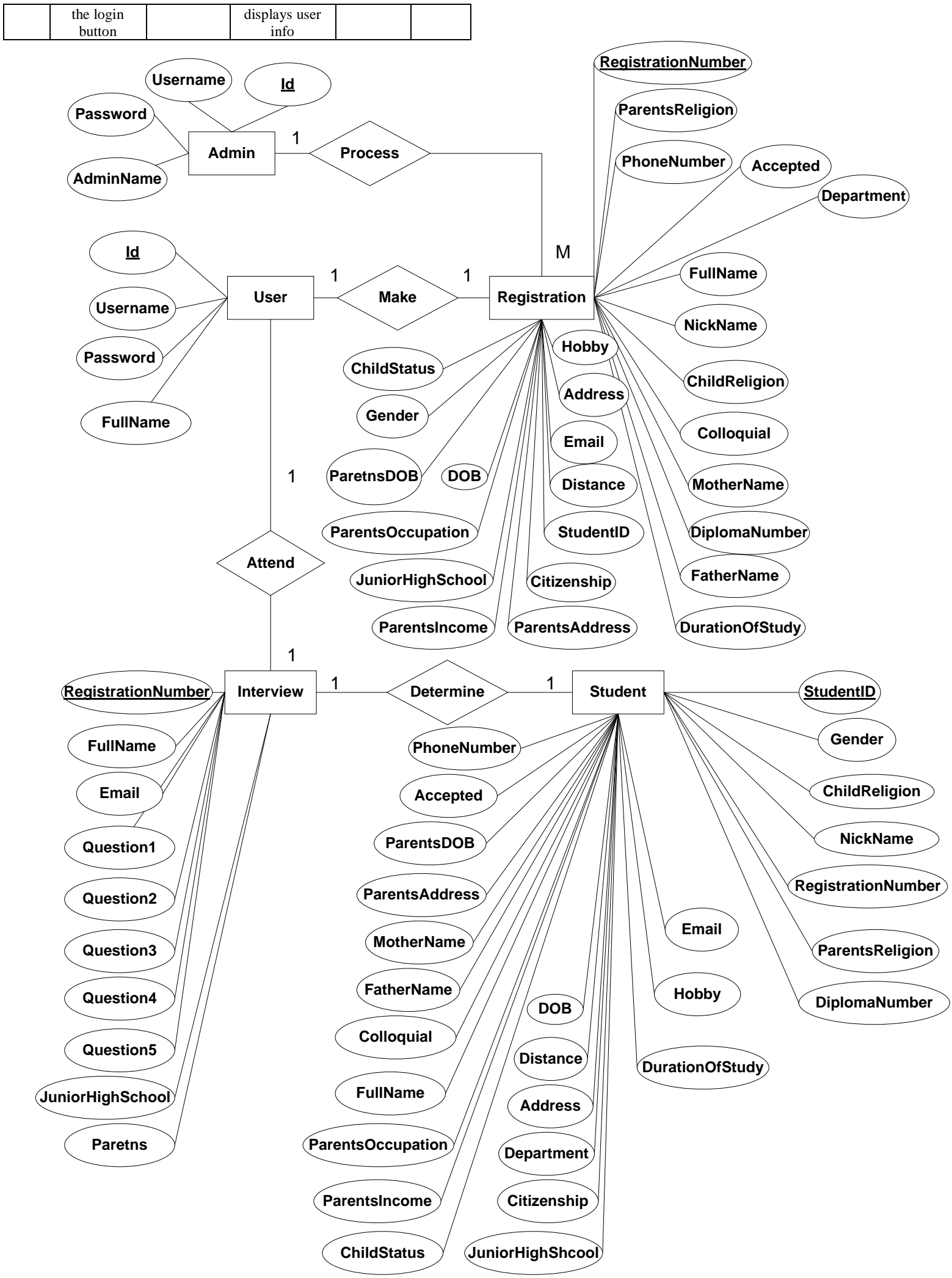

Fig. 2. Entity Relationship Diagram 


\section{CONCLUSION}

Based on the discussion, conclusions can be drawn about the new student admission information system project as follows:

1) Can save the time needed to register new students to be more efficient because it has been supported by an integrated system.

2) It is expected to produce information that is fast, precise and accurate.

3) Improve the quality and efficiency of the implementation of new student admission registration.

\section{REFERENCES}

[1] D. B. Rahayu, E. Gunadhi, and Partono, "Perancangan Sistem Informasi Pendaftaran Peserta Didk Baru Berbasis Web Studi Kasus di SMA Negeri 14 Garut," J. Algoritm., vol. 09, no. 27, pp. 1-7, 2012.

[2] N. H. Cahyana, E. Y. Prasetyo, and H. Himawan, "Aplikasi Penerimaan Siswa Baru Berbasis Web (SMK Negeri 3 Yogyakarta)," J. Telemat., vol. 10, no. 1, pp. 1-8, 2013.

[3] S. Bahri and S. Dalis, "Rancang Bangun E-Enrollment Berbasis Web Menggunakan Customer Relationship Management (CRM) Pada Sekolah Dasar Islam Terpadu," $J$. Tek. Komput., vol. 4, no. 1, pp. 205-211, 2018.

[4] I. Sommerville, Software Engineering Ninth Edition. Pearson Education, Inc, 2011.

[5] C. J. Date, "An Introduction to Database Systems." Pearson Education, Inc, p. 1024, 2004.

[6] J. Rumbaugh, I. Jacobson, and G. Booch, The Unified Modeling Language Reference Manual, Second Edition, no. 2. Boston: Pearson Education, Inc, 2005.

[7] A. Dennis, B. H. Wixom, and D. Tegarden, Systems Analysis and Design with UML. 2012. 